\title{
Childhood Arterial Ischaemic Stroke: Clinical Presentation, Risk Factors and Management
}

\author{
Lucia Gerstl ${ }^{1}$ Michaela V. Bonfert ${ }^{1} \quad$ Florian Heinen $^{1}$ Martin Olivieri ${ }^{2}$ Andreas Sebastian Schroeder ${ }^{1}$ \\ Moritz Tacke ${ }^{1}$ Karin Kurnik ${ }^{2}$ Christoph Bidlingmaier ${ }^{2}$ Karl Reiter ${ }^{3}$ Ingo Borggraefe ${ }^{1}$
}

\footnotetext{
${ }^{1}$ Division of Paediatric Neurology and Developmental Medicine, Department of Paediatrics, LMU Munich, University Hospital, Dr. von Hauner Children's Hospital, Munich, Germany

2 Division of Paediatric Hemostasis and Thrombosis, Department of Paediatric, LMU Munich, University Hospital, Dr. von Hauner Children's Hospital, Munich, Germany

3 Division of Paediatric Intensive Care Medicine, Department of Paediatrics, LMU Munich, University Hospital, Dr. von Hauner Children's Hospital, Munich, Germany
}

Address for correspondence Lucia Gerstl, MD, Division of Paediatric Neurology and Developmental Medicine, Department of Paediatrics, LMU Munich, University Hospital, Dr. von Hauner Children's Hospital, LMU Center for Development and Children with Medical Complexity, Lindwurmstr. 4, 80337 Munich, Germany (e-mail: lucia.gerstl@med.Imu.de).

Hämostaseologie 2020;40:165-173.

\section{Abstract \\ Keywords \\ - paediatric stroke \\ - management \\ - risk factors \\ - symptoms}

Zusammenfassung

\section{Schlüsselwörter}

- Schlaganfall

- Pädiatrie

- Symptome

- Risikofaktoren

- Therapie
Childhood arterial ischaemic stroke (AIS) is a rare, but potentially life-threatening event which requires early diagnosis and adequate treatment. The reported significant time delay to childhood AIS diagnosis may be associated with low awareness, the more nonspecific clinical presentation as well as difficult clinical differentiation to more common "stroke mimics" and a less established "acute care structure" with delayed access to proper neuroimaging. Compared with adult stroke care, experiences with acute reperfusion therapies like thrombolysis and mechanical thrombectomy are promising but limited and not based on clinical trials. The etiological work-up is absolutely essential, as the child's individual risk profile determines acute management, secondary prevention, risk of recurrence and outcome. Follow-up care should be organized in a multidisciplinary setting covering all bio-psycho-social aspects to achieve the best integration of the child into its educational, later professional and social environments.

Der Schlaganfall im Kindes- und Jugendalter ist ein seltenes, aber potentiell lebensbedrohliches Ereignis und erfordert rasche Diagnosestellung und Therapie. Aufgrund der geringen Awareness, der häufigen unspezifischen klinsichen Präsentation mit einer Fülle zu bedenkender, wahrscheinlicherer Differenzialdiagnosen sowie der noch wenig etablierten Versorgungsstrukturen wird der kindliche Schlaganfall oft erst mit einer deutlichen Zeitverzögerung diagnostiziert. In der Erwachsenenneurologie etablierte Revaskularisationstherapien können in der Pädiatrie aktuell nur als off-label Therapien mit begrenzten Erfahrungen eingesetzt werden. Die ätiologische Abklärung ist unabdingbar, bestimmt doch das individuelle Risikoprofil neben Akutmanagement und Rezidivprophylaxe auch das Rezidivrisiko und Outcome. Die Langzeitbetreuung der betroffenen Kinder und Jugendlichen sollte im multidisziplinären Setting unter Berücksichtigung aller bio-psycho-sozialer Aspekte erfolgen. Denn neben dem klinisch neurologischen Outcome sind insbesondere auch die Auswirkungen des Schlaganfalls auf Kognition und Verhalten für eine erfolgreiche Integration des Kindes in sein schulisches und soziales Umfeld mitentscheidend. received

August 7, 2019

accepted after revision

February 25, 2020 (c) 2020 Georg Thieme Verlag KG Stuttgart . New York
DOI https://doi.org/ 10.1055/a-1113-0445. ISSN 0720-9355. 


\section{Introduction}

With an incidence of 1-8/100,000 children per year, childhood stroke is rare, but causes significant morbidity and mortality. ${ }^{1-4}$ It can occur at any age with incidence peaks in infants, toddlers and adolescents with a significant male predominance in the latter age group. Low awareness for childhood stroke among parents and health care providers, in-hospital delay in proper diagnostic/imaging and the broad list of more likely "stroke mimics" lead to an average time gap of 24 hours between clinical onset of symptoms and diagnosis. .,6 $^{\text {. }}$

The following review provides an overview of clinical presentation, risk factors and management of childhood arterial ischaemic stroke (AIS) in infants, children and adolescents ( $>28$ days of life to $\leq 18$ years).

\section{Clinical Presentation}

Independent of age, the majority of children present with an acute focal neurological deficit such as acute hemiparesis, facial palsy and speech disturbance. ${ }^{4,5,7-9}$ Therefore, the "Face Arm Speech Time-FAST test"-developed as an early recognition tool for adult stroke, can also be used as a screening tool in childhood stroke with a satisfactory sensitivity of approximately $76 \%{ }^{10}$ The sensitivity of the beFAST test $(b=$ balance, $\mathrm{e}=$ eyes) may be even higher but has not been evaluated systematically so far. There are, however, some additional age-specific clinical features which might complicate the diagnosis of childhood stroke, like the initial presentation with seizures especially in infants and very young children (up to approximately 50\%) and headache in school children and adolescents (approximately 30\%)., ${ }^{4,11-13}$ A stuttering course is described especially in children with intracranial arteriopathy, either transient or chronic (sickle cell disease, moyamoya, etc.). In general, it should be noted that the younger the child, the more nonspecific the clinical presentation of ischaemic stroke can be. To increase awareness for stroke in children, the paediatric stroke working group of the Ludwig-Maximilians-University Munich developed a pocket card for paediatricians called MERCS (Munich Early Recognition of Childhood Stroke) highlighting the beFAST test and additional information for both ischaemic and haemorrhagic stroke ( - Fig. 1).

Besides additional nonspecific clinical presentation, also well-known and more frequently occurring "stroke mimics" like complex migraine, seizures or idiopathic facial palsy could delay the diagnosis of childhood stroke. ${ }^{11,14,15}$

\section{Risk Factors}

The main risk factors for ischaemic stroke in adults like atrial fibrillation, arterial hypertension or diabetes mellitus are not relevant in childhood stroke. A large number of different risk factor categories need to be considered in the diagnostic work-up of children and adolescents like cardiac diseases, arteriopathies, infections, prothrombotic states, metabolic or other genetic diseases. ${ }^{4,7,16-19}$ An overview of possible risk factor categories and examples within the categories are listed in -Table 1.
Childhood stroke is known to be a multiple-risk disease, meaning that in a relevant proportion of the affected children the presence and interaction of different risk factors lead to the ischaemic stroke-a fact which also seems to worsen outcome. ${ }^{20,21}$ In 10 to $20 \%$ of children, so far no known risk factor hasbeen detected in a thorough diagnostic work-up and stroke is therefore classified as "cryptogenic".

The Childhood AIS Standardized Classification and Evaluation (CASCADE) criteria, established in 2012 as a comprehensive classification system, allows a uniform nomenclature and classification in childhood AIS. ${ }^{22,23}$ CASCADE classification on admission was also shown to be associated with risk of stroke recurrence and with different courses of the arteriopathy. ${ }^{24}$ The primary (acute/chronic) and secondary CASCADE criteria are summarized in -Table 2.

\section{Arteriopathies}

Arteriopathies are one of the leading causes of childhood stroke (up to 50\%) and, furthermore, are a strong predictor of recurrent stroke. ${ }^{4,18,25}$ The most common are the focal cerebral arteriopathy (up to 30\%), the cerebrovascular dissection (up to $10 \%$ ) and the Moyamoya angiopathy. With the progress in genetic testing and knowledge, arteriopathies on the basis of a genetic disorder are more and more diagnosed. ${ }^{26}$

\section{Transient Cerebral Arteriopathy (Synonyms: Transient} Focal Arteriopathy, Focal Cerebral Arteriopathy) This unilateral arteriopathy mostly affects the distal internal cerebral artery, the proximal middle cerebral artery or the proximal anterior cerebral artery. ${ }^{27-30}$ Though transient cerebral arteriopathy (TCA) shows a self-limiting course without progression after 6 to 12 months, a rapid aggravation in the first days to weeks is possible and responsible for a high risk of recurrent stroke in this phase. The pathophysiology is not completely understood, but a post-/parainfectious inflammatory process of the vessel wall is considered being responsible for swelling and subsequently for occlusion of the vessel. Post-varicella-arteriopathy is the most known reason for a TCA and can occur weeks to months after the acute infection with varicella zoster virus. $^{31,32}$ Still, other infectious pathogens such as herpes simplex virus, Borrelia burgdorferi or enterovirus should also be checked for.

-Fig. 2 shows typical magnetic resonance imaging (MRI) findings in TCA with narrowing and irregularity of the affected vessel ( - Fig. 2A) and contrast enhancement of the vessel wall as a sign for the active inflammatory process (-Fig. 2B).

\section{Cerebrovascular Dissection}

Dissections are a relevant cause for childhood stroke and are mainly triggered by (trivial) trauma during sports or playing activities. ${ }^{18,33}$ Predisposing factors may be genetic connective tissue disorders like Marfan syndrome or Ehlers-Danlos syndrome, but also arteriopathies leading to vulnerable vessel walls are considered to be a relevant risk factor. The differentiation from intracerebral dissections to focal cerebral arteriopathies may be challenging. ${ }^{34}$ 


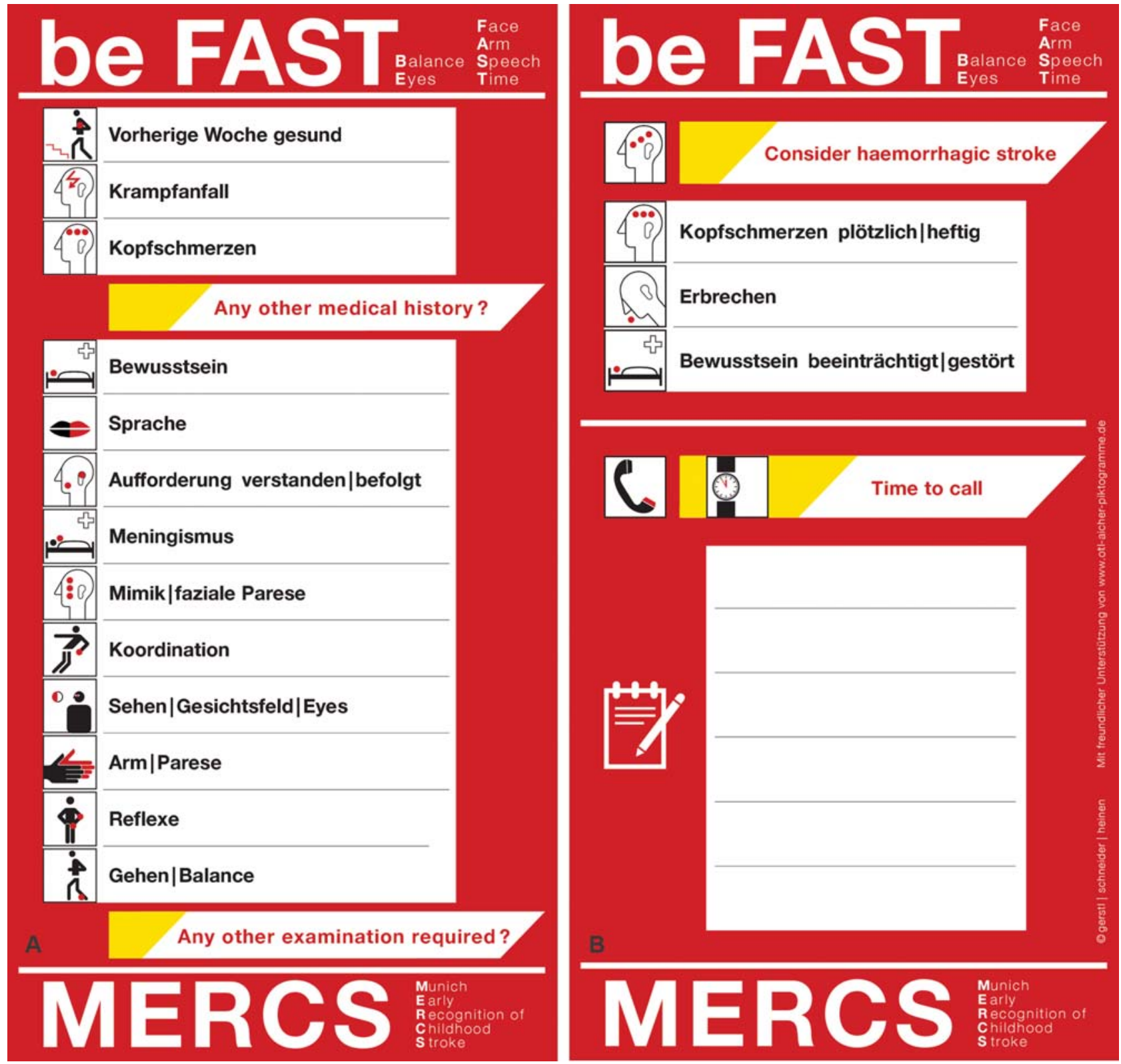

Fig. 1 Pocketcard MERCS-Munich Early Recognition of Childhood Stroke. Besides the stroke recognition tool beFAST on the top, it provides relevant clinical information about both childhood ischaemic and haemorrhagic stroke on the front and back side of the card. (Front: childhood ischaemic stroke: well in the week before presentation? Seizures? Headache? Back: consider haemorrhagic stroke: headache "sudden"; "worst"; vomiting; decreased level of consciousness). A structured emergency examination for time-critical neurological disorders is also illustrated: level of consciousness? Speech? Understands and follows instructions? Meningism I Neck stiffness? Facial palsy? Coordination? Visual disturbance? Hemiparesis? Tendon reflexes? Walking I Balance? There is additional free space on the back side for hospital-specific emergency telephone numbers.

\section{Moyamoya Angiopathy}

Moyamoya angiopathy is a cerebrovascular disease with a progressive narrowing of the distal internal cerebral artery or middle cerebral artery leading to compensatory collaterals described in angiography as the characteristic "puffy smoke". ${ }^{35}$ Moyamoya can be primary (idiopathic) or secondary to other underlying disorders such as sickle cell disease, trisomy 21 or neurofibromatosis. Knowledge about genetics underlying Moyamoya angiopathy [e.g.,Ring finger 213 (RNF213) gene] is increasing, as is about related changes in circulating factors and the response to environmental factors. ${ }^{36}$

\section{Arteriopathies with a Genetic Predisposition}

Under certain circumstances, a work-up for genetic arteriopathies is reasonable: these could be the co-occurrence of ischaemic and haemorrhagic strokes (in the child or in the family) or the presence of almost pathognomonic additional symptom combinations like recurrent fever with livedo racemosa and hepatosplenomegaly in ADA2 deficiency. ${ }^{26}$ 
Table 1 Possible risk factors in childhood AIS, adapted from Gerstl et al ${ }^{19}$

\begin{tabular}{|c|c|}
\hline Arteriopathy & $\begin{array}{l}\text { Transient cerebral arteriopathy } \\
\text { Primary CNS vasculitis } \\
\text { Para-/post-infectious vasculitis } \\
\text { Arterial dissection (extra-/intracranial) } \\
\text { Moyamoya angiopathy } \\
\text { Fibromuscular dysplasia } \\
\text { Systemic lupus erythematosus } \\
\text { Other }\end{array}$ \\
\hline Infectious disease & $\begin{array}{l}\text { Varicella zoster virus, Borrelia burgdorferi, mycoplasma pneumonia, } \\
\text { enterovirus, parvovirus, herpes simplex virus, other } \\
\text { Meningitis (Streptococcus pneumoniae, mycobacterium tuberculosis) } \\
\text { In general: sepsis, dehydration }\end{array}$ \\
\hline Cardiac & $\begin{array}{l}\text { Congenital/acquired heart disease } \\
\text { Patent foramen ovale } \\
\text { Endocarditis } \\
\text { Cardiomyopathy } \\
\text { Previous cardiac surgery/catheterization } \\
\text { Mechanical circulatory support } \\
\text { Arrhythmia } \\
\text { Other }\end{array}$ \\
\hline Prothrombotic state & $\begin{array}{l}\text { Protein C deficiency } \\
\text { Protein S deficiency } \\
\text { Prothrombin mutation (G20210A) } \\
\text { Factor V Leiden (G1691A) } \\
\text { MTHFR (C677T) } \\
\text { Hyperhomocysteinaemia } \\
\text { Elevated lipoprotein (a) } \\
\text { Antithrombin deficiency } \\
\text { Increased factor VIII (permanently }>150 \%) \\
\text { Lupus anticoagulants and antiphospholipid antibody syndrome }\end{array}$ \\
\hline Haemato-oncological & $\begin{array}{l}\text { Sickle cell disease } \\
\text { Haemolytic anaemia } \\
\text { Other }\end{array}$ \\
\hline Genetic predisposition & $\begin{array}{l}\text { Trisomy } 21 \\
\text { Neurofibromatosis type } 1 \\
\text { PHACE syndrome } \\
\text { Mutation: ACTA2, ADA2 (CECR1 gene), SMAD3, Col4A1, Col4A2 }\end{array}$ \\
\hline Metabolic & $\begin{array}{l}\text { Mitochondriopathy } \\
\text { Fabry disease } \\
\text { Homocystinuria } \\
\text { CDG syndrome } \\
\text { Other }\end{array}$ \\
\hline Other & $\begin{array}{l}\text { Medication/therapy (oral contraceptives, radiation, etc.) } \\
\text { Connective tissue disorders (Ehlers-Danlos syndrome, Marfan syndrome, osteogenesis imperfecta) } \\
\text { Cerebrovascular anomalies (aneurysm, arteriovenous malformation, cavernoma) } \\
\text { Brain tumour } \\
\text { Previous neurosurgical procedure } \\
\text { Migraine }\end{array}$ \\
\hline
\end{tabular}

Abbreviations: AIS, arterial ischaemic stroke; CDG, congenital disorders of glycosylation; CNS, central nervous system.

Some other known mutations leading to ischaemic strokes are listed in -Table 1.

\section{Infectious Diseases}

Infectious diseases are an important risk factor for childhood AIS and could be one reason for the incidence peak in infants and very young children. Even "minor infections" like upper respiratory tract infections or otitis media have been shown to increase the risk for ischaemic stroke up to sixfold. ${ }^{37-39}$ Ischaemic stroke is also a known complication in bacterial or tuberculous meningitis. In general, a broad list of infectious pathogens can trigger the above-described transient focal arteriopathy leading to a stroke.

\section{Cardiac Diseases}

Cardiac diseases are one of the top causes for childhood stroke. These include congenital heart diseases, cardiomyopathies, endocarditis, cardiac surgery or cardiac catheter examination and mechanical circulatory support. ${ }^{4,17,40} \mathrm{~A}$ paradoxical embolism from a patent foramen ovale as a 
Table 2 CASCADE criteria, adapted from Bernard et al 22,23

\begin{tabular}{|c|c|c|}
\hline \multirow{2}{*}{$\begin{array}{l}\text { Primary classification } \\
\text { (only one selected) }\end{array}$} & Basic subtype (7) & Expanded subtype (19) \\
\hline & $\begin{array}{l}\text { 1. Small vessel arteriopathy in childhood } \\
\text { 2. Unilateral focal cerebral arteriopathy in childhood } \\
\text { 3. Bilateral focal cerebral arteriopathy in childhood } \\
\text { 4. Aortic/cervical arteriopathy } \\
\text { 5. Cardioembolic } \\
\text { 6. Other } \\
\text { 7. Multifactorial }\end{array}$ & Further classification of basic subtypes \\
\hline $\begin{array}{l}\text { Secondary classification } \\
\text { (select as many as apply) }\end{array}$ & \multicolumn{2}{|l|}{$\begin{array}{l}\text { 1. Genetic: vasculopathy } \\
\text { 2. Infectious } \\
\text { 3. Haematological/thrombotic } \\
\text { 4. Inflammatory } \\
\text { 5. Genetic: metabolic } \\
\text { 6. Drug/toxin exposure } \\
\text { 7. Vasospasm }\end{array}$} \\
\hline
\end{tabular}
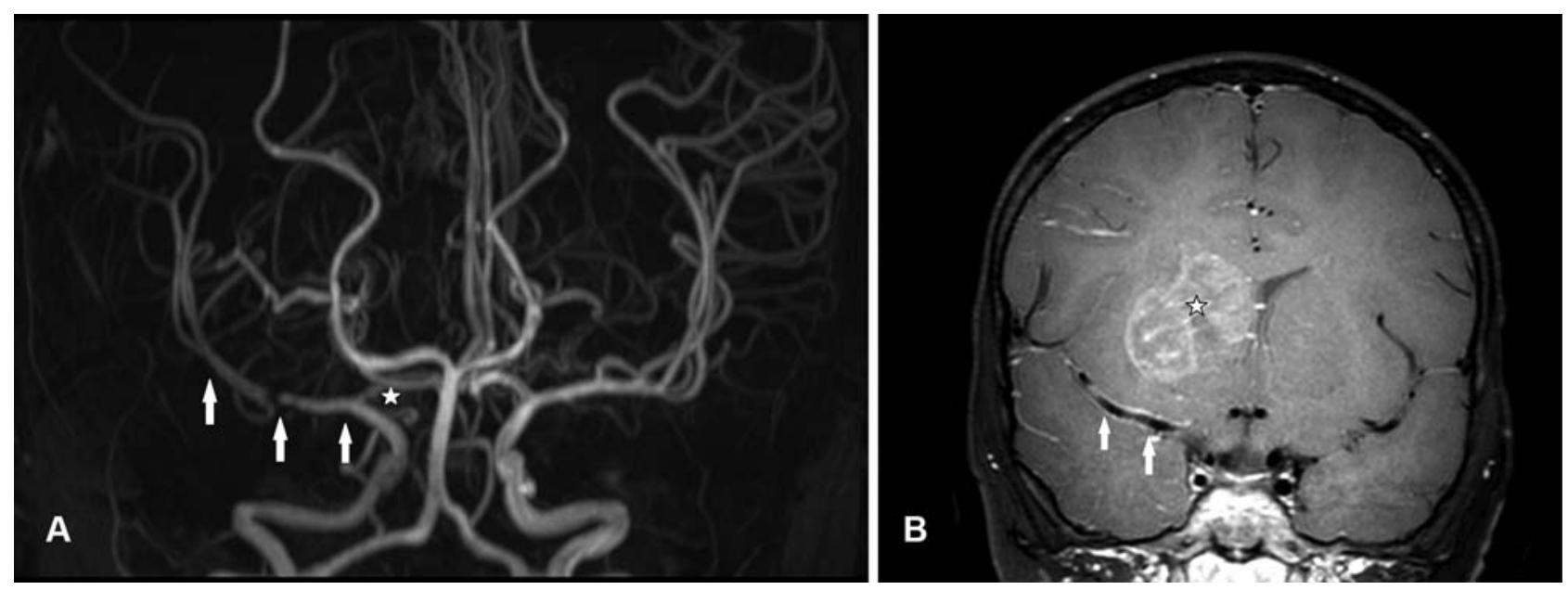

Fig. 2 Five-year old boy with TCA. (A) Three-dimensional time-of-flight magnetic resonance angiography image with a focal severe stenosis and irregularity of the right middle cerebral artery (MCA;white arrows) and milder irregularity of the right anterior cerebral artery (A1 segment;white asterisk). (B) Contrast-enhanced black blood vessel wall imaging shows a vessel wall enhancement of the right MCA (white arrows) (asterisk: right basal ganglia infarction). TCA, transient cerebral arteriopathy.

single cause of an ischaemic stroke in children remains a diagnosis reached by an exclusionary process. ${ }^{41}$

\section{Prothrombotic States}

The influence of prothrombotic risk factors in the etiology of childhood stroke is well described and differs from the prothrombotic risk factor itself, an isolated versus combined occurrence and the co-existence of further, non-prothrombotic risk factors. ${ }^{42,43}$

\section{Diagnosis}

\section{Imaging}

A cranial MRI is described to be the gold standard in the diagnosis of childhood AIS with its obvious potential in the proof of a recent stroke as well as in the differentiation to the multiple, more common stroke mimics. A short, lasting 10 to 20 minutes, hyperacute MRI protocol is recommended to make the initial diagnosis leading to the hyperacute man- agement. ${ }^{6,12,44,45}$ This rapid MRI should include the following sequences:

- Diffusion-weighted imaging and apparent diffusion coefficient.

- Susceptibility-weighted imaging.

- Cervical and cerebral three-dimensional time-of-flight magnetic resonance angiography.

- Fluid-attenuated inversion recovery.

Follow-up MRIs include further sequences and, considering the high incidence of arteriopathies in childhood AIS, should also focus on a proper vessel wall imaging. ${ }^{25}$

If initial cranial MRI imaging would not be feasible within a short time due to any circumstances, initial diagnosis is done with a cranial computed tomography (CT) as it is in a critically ill child with a reduced level of consciousness. But one should keep in mind its lower sensitivity in the early hours after stroke and regarding stroke mimics compared with an initial MRI as well as the diagnostic limits concerning 
the posterior fossa. The radiation exposure is a further argument for the restricted use of a CT in children.

A conventional angiography may be necessary in the postacute setting in some children for further etiological work-up or treatment planning (e.g., in children with Moyamoya). Transcranial color-coded sonography is regularly recommended in patients with sickle cell disease (the most frequent risk factor for childhood stroke worldwide) and may also be helpful in monitoring of cerebral arteriopathies. ${ }^{46}$

\section{Further Diagnostics}

With respect to the broad list of possible risk factors and childhood AIS as a multiple-risk disease, the authors recommend basis laboratory testing for each child including screening for infectious diseases, vasculitis, prothrombotic risk factors, metabolic diseases, etc. In some cases (see above), genetic testing may also be indicated. An echocardiography and electrocardiogram are also part of the basis work-up in childhood stroke. The extended diagnostic workup depends amongst others on medical history, results of neuroimaging, CASCADE classification and any further etiological hints. ${ }^{47,48}$

\section{Management}

\section{Thrombolysis and Mechanical Thrombectomy}

So far, there are no published clinical trials investigating efficacy and safety of thrombolysis and mechanical thrombectomy in childhood AIS. The Thrombolysis in Paediatric Stroke Study (TIPS), created as an international multicentre, dose-adaptive cohort study, has been closed in 2013 because of unsuccessful recruitment-which underlines the probably insurmountable difficulties of conducting randomized clinical trials in childhood stroke. ${ }^{49}$ The results of several randomized open-label placebo-controlled endovascular trials in adult stroke, using newer generation clot retrieval devices, cannot be directly transferred to the paediatric population due to the above-mentioned different aspects. ${ }^{50-54}$ Therefore, the decision for intravenous thrombolysis or an endovascular therapy as an "off-label" therapy must be made as a case-by-case decision by a multidisciplinary team in specialized (paediatric) stroke centres after a thorough risk-benefit analysis. However, there has been an increasing number of published case reports and case-series describing thrombolysis and endovascular therapy as a feasible and promising treatment option even in very young children. ${ }^{55-59}$ The recently published results of the Save ChildS Study, investigating feasibility, safety and outcome of endovascular recanalization of childhood AIS, are encouragingly positive. ${ }^{60}$ In this retrospective, multicentrecohort study on 73 children treated in 27 international stroke centres, the safety profile of mechanical thrombectomy was comparable to those in randomized clinical trials for adults and outcome of most of the treated children was favourable.

\section{Antithrombotic Therapy}

If thrombolysis and thrombectomy are no treatment options, initial antithrombotic therapy is started with unfractionated heparin, low-molecular-weight heparin or acetylsalicylic acid (ASA), which may be switched after etiological classification. ${ }^{47,48,61,62}$ In children with cardioembolic stroke or a stroke caused by a cervical arterial dissection, low-molecular-weight heparin or Vitamin K antagonists are recommended, whereas children with other underlying etiologies should be treated with ASA. ${ }^{63}$ So far, direct oral anticoagulants are not licensed for the use in children. An overview of the most common antithrombotic agents is shown in - Table $3 .^{64}$ The treatment duration depends on the underlying condition, the risk of recurrent strokes and imaging results. ${ }^{47}$ Most children are treated for at least 2 years.

To standardize and optimize the use of antithrombotic therapy in childhood AIS, further studies with a focus, amongst others, on efficacy, dosing, impact of developmental haemostasis, treatment monitoring and duration are needed. ${ }^{65}$

Table 3 Overview of the most common antithrombotic agents, adapted from Kurnik et al ${ }^{64}$

\begin{tabular}{|c|c|}
\hline Antithrombotic agent & Dosage \\
\hline Unfractionated heparin & $\begin{array}{l}(100)-300-600 \mathrm{U} / \mathrm{kg} / \mathrm{d} \\
\text { or rather: } 50 \mathrm{U} / \mathrm{kg} \text { as a bolus over } 10 \mathrm{~min} \text {, then: }<1 \mathrm{y}: 20-30 \mathrm{U} / \mathrm{kg} / \mathrm{h},>1 \mathrm{y} \text { : } \\
20-25 \mathrm{U} / \mathrm{kg} / \mathrm{h} \\
\text { target: } \mathrm{PTT}(50)-60-85 \mathrm{~s} \text {, Antithrombin should be } 60-80 \%\end{array}$ \\
\hline LMWH & $\begin{array}{l}\text { Enoxaparin: } \\
<2 \mathrm{mo}^{\mathrm{a}}: 1.5 \mathrm{mg} / \mathrm{kg} 1-2 \times / \mathrm{d} \mathrm{sc}(0.75 \mathrm{mg} / \mathrm{kg} \text { as prophylaxis }) \\
>2 \mathrm{mo}^{\mathrm{a}}: 1.0-1.5 \mathrm{mg} / \mathrm{kg} 1-2 \mathrm{x} / \mathrm{d} \mathrm{sc}(0.5 \mathrm{mg} / \mathrm{kg} \text { as prophylaxis }) \\
\text { Dalteparin: } 100-150-200 \mathrm{U} / \mathrm{kg} / \mathrm{d} \mathrm{sc}\end{array}$ \\
\hline Acetylsalicylic acid & $(1-) 3-5 \mathrm{mg} / \mathrm{kg} / \mathrm{d}$ (max: $100 \mathrm{mg} / \mathrm{d})$ \\
\hline Clopidogrel & $1 \mathrm{mg} / \mathrm{kg} 1 \times / \mathrm{d}$ \\
\hline Phenprocoumon & $\begin{array}{l}\text { Day } 1: 0.2-0.3 \mathrm{mg} / \mathrm{kg} / \mathrm{d} \\
\text { Day 2: } 50 \% \text { of the initial dosage } \\
\text { From day } 3 \text { : adjust according to INR }\end{array}$ \\
\hline Warfarin & $\begin{array}{l}\text { Day } 1: 0.2 \mathrm{mg} / \mathrm{kg} 1 \times / \mathrm{d} \text { p.o. } \\
\text { From day } 2: 0.05-0.2 \mathrm{mg} / \mathrm{kg} 1 \times / \mathrm{d} \text { p.o. (adjust according to INR) }\end{array}$ \\
\hline
\end{tabular}

Abbreviations: INR, international normalized ratio; LMWH, low-molecular-weight heparin;p.o., orally; PTT, partial thromboplastin time;sc, subcutaneously. an clinical practice, not only infants $<2$ months need higher dosages of LMWH,an adjustment according to target anti-FXa levels is obligatory. 


\section{Steroids/Immunosuppressive Therapy}

In patients with primary small or large vessel central nervous system vasculitis, steroids and in some cases further immunosuppressive therapy are well established. ${ }^{12}$ In a retrospective study, the addition of steroids to antiplatelet therapy showed some positive effects in children with transient focal arteriopathy, but this benefit has to be proven in larger clinical trials. $^{66}$

\section{Risk of Recurrence/Outcome}

The risk of recurrence is between 6 and $40 \%$, but depends on each child's individual risk factor profile. ${ }^{7,67,68}$ Children with no or a single known risk factor have a substantially lower risk of recurrence than children with multiple risk factors. The highest risk of recurrence is described in children with some stenosing arteriopathies like Moyamoya angiopathy or with sickle cell disease. With respect to prothrombotic risk factors, an elevated lipoprotein (a), a heterozygous antithrombin deficiency and the presence of more than one prothrombotic risk factor are independently associated with an increased risk of AIS recurrence. ${ }^{69}$

Physical and motor impairments (especially hemiparesis with post-stroke spasticity) are common and affect almost two-thirds of childhood stroke patients. Larger cortical lesions and the occurrence of acute seizures (as presenting symptom) or seizures in the early post-stroke period (within 24-48 hours) significantly increase the risk for a post-stroke epilepsy, which develops in 13 to $24 \%$ of the children. ${ }^{70-72}$ Lower health-related quality of life was demonstrated in childhood stroke survivors compared with the reference population. ${ }^{73}$ Follow-up care after childhood AIS should include all bio-psycho-social aspects and should therefore also focus on further life-changing sequela like fatigue, attention deficits, cognitive decline and psychiatric comorbidities, and last but not least the burden of stroke suffered by the whole family of the affected child.

\section{Conclusion}

Childhood AIS is an emergency-Time is brain!

Fortunately, there has been a considerable effort to improve management of childhood AIS over the last few years: raising awareness for childhood stroke, developing childhood stroke recognition tools, the implementation of paediatric stroke protocols with quick access to proper neuroimaging and increasing experience in endovascular treatment are just a few illustrating examples. Facing the difficulties of conducting large randomized controlled trials in childhood AIS and produce robust evidence, paediatric neurovascular teams should be encouraged to collaborate in paediatric stroke networks, nationally and internationally, to increase knowledge about this rare disease with all its complexity.

\section{Conflict of Interest}

None declared.

\section{References}

1 Fullerton $\mathrm{HJ}$, Wu YW, Zhao S, Johnston SC. Risk of stroke in children: ethnic and gender disparities. Neurology 2003;61 (02):189-194

2 Giroud M, Lemesle M, Gouyon JB, Nivelon JL, Milan C, Dumas R. Cerebrovascular disease in children under 16 years of age in the city of Dijon, France: a study of incidence and clinical features from 1985 to 1993. J Clin Epidemiol 1995;48(11):1343-1348

3 Lynch JK, Hirtz DG, DeVeber G, Nelson KB. Report of the National Institute of Neurological Disorders and Stroke workshop on perinatal and childhood stroke. Pediatrics 2002;109(01): 116-123

4 Mallick AA, Ganesan V, Kirkham FJ, et al. Childhood arterial ischaemic stroke incidence, presenting features, and risk factors: a prospective population-based study. Lancet Neurol 2014;13 (01):35-43

5 Gerstl L, Weinberger R, von Kries R, et al. Symptom patterns in childhood arterial ischemic stroke: analysis of a population-based study in Germany. Klin Padiatr 2018;230(06):319-325

6 Mallick AA, Ganesan V, Kirkham FJ, et al. Diagnostic delays in paediatric stroke. J Neurol Neurosurg Psychiatry 2015;86(08): 917-921

7 Steinlin M. A clinical approach to arterial ischemic childhood stroke: increasing knowledge over the last decade. Neuropediatrics 2012;43(01):1-9

8 Steinlin M, Pfister I, Pavlovic J, et al; Swiss Societies of Paediatric Neurology and Neonatology. The first three years of the Swiss Neuropaediatric Stroke Registry (SNPSR): a population-based study of incidence, symptoms and risk factors. Neuropediatrics 2005;36(02):90-97

9 Kossorotoff M, Chabrier S, Tran Dong K, Nguyen The Tich S, Dinomais M. Arterial ischemic stroke in non-neonate children: diagnostic and therapeutic specificities. Rev Neurol (Paris) 2020; 176(1-2):20-29

10 Yock-Corrales A, Babl FE, Mosley IT, Mackay MT. Can the FAST and ROSIER adult stroke recognition tools be applied to confirmed childhood arterial ischemic stroke? BMC Pediatr 2011;11:93

11 Mackay MT, Monagle P, Babl FE. Brain attacks and stroke in children. J Paediatr Child Health 2016;52(02):158-163

12 Steinlin M, Mackay MT. Emergency management of ischemic stroke in children. Curr Treat Options Neurol 2015;17(05):349

13 Gerstl L, Weinberger R, Heinen F, et al. Arterial ischemic stroke in infants, children, and adolescents: results of a Germany-wide surveillance study 2015-2017. J Neurol 2019;266(12):29292941

14 Mackay MT, Chua ZK, Lee M, et al. Stroke and nonstroke brain attacks in children. Neurology 2014;82(16):1434-1440

15 Mackay MT, Lee M, Yock-Corrales A, et al. Differentiating arterial ischaemic stroke from migraine in the paediatric emergency department. Dev Med Child Neurol 2018;60(11):1117-1122

16 Gerstl L, Heinen F, Borggraefe I, et al. Paediatric Stroke - a paediatric neurological emergency. Symptoms, diagnostic strategies and management. Monatsschr Kinderheilkd 2017; 165:408-415

17 Gerstl L, Weinberger R, von Kries R, et al. Risk factors in childhood arterial ischaemic stroke: findings from a population-based study in Germany. Eur J Paediatr Neurol 2018;22(03):380-386

18 Mackay MT, Wiznitzer M, Benedict SL, Lee KJ, Deveber GA, Ganesan V; International Pediatric Stroke Study Group. Arterial ischemic stroke risk factors: the International Pediatric Stroke Study. Ann Neurol 2011;69(01):130-140

19 Gerstl L, Bonfert MV, Nicolai T, et al. Childhood stroke: What are the special features of childhood stroke? [in German]. Nervenarzt 2017;88(12):1367-1376

20 deVeber G. Stroke and the child's brain: an overview of epidemiology, syndromes and risk factors. Curr Opin Neurol 2002;15(02): 133-138 
21 Lanthier S, Carmant L, David M, Larbrisseau A, de Veber G. Stroke in children: the coexistence of multiple risk factors predicts poor outcome. Neurology 2000;54(02):371-378

22 Bernard TJ, Beslow LA, Manco-Johnson MJ, et al. Inter-rater reliability of the CASCADE criteria: challenges in classifying arteriopathies. Stroke 2016;47(10):2443-2449

23 Bernard TJ, Manco-Johnson MJ, Lo W, et al. Towards a consensusbased classification of childhood arterial ischemic stroke. Stroke 2012;43(02):371-377

24 Böhmer M, Niederstadt T, Heindel W, et al. Impact of childhood arterial ischemic stroke standardized classification and diagnostic evaluation classification on further course of arteriopathy and recurrence of childhood stroke. Stroke 2018 (e-pub ahead of print). Doi: 10.1161/STROKEAHA. 118.023060

25 Goyal P, Malhotra A, Almast J, et al. Neuroimaging of pediatric arteriopathies. J Neuroimaging 2019;29(03):287-308

26 Munot P, Crow YJ, Ganesan V. Paediatric stroke: genetic insights into disease mechanisms and treatment targets. Lancet Neurol 2011;10(03):264-274

27 Braun KP, Bulder MM, Chabrier S, et al. The course and outcome of unilateral intracranial arteriopathy in 79 children with ischaemic stroke. Brain 2009;132(Pt 2):544-557

28 Kirton A, deVeber G. Paediatric stroke: pressing issues and promising directions. Lancet Neurol 2015;14(01):92-102

29 Fullerton HJ, Stence N, Hills NK, et al; VIPS Investigators. Focal cerebral arteriopathy of childhood: novel severity score and natural history. Stroke 2018;49(11):2590-2596

30 Chabrier S, Sébire G, Fluss J. Transient cerebral arteriopathy, postvaricella arteriopathy, and focal cerebral arteriopathy or the unique susceptibility of the M1 segment in children with stroke. Stroke 2016;47(10):2439-2441

31 Amlie-Lefond C, Gilden D. Varicella zoster virus: a common cause of stroke in children and adults. J Stroke Cerebrovasc Dis 2016;25 (07):1561-1569

32 Lanthier S, Armstrong D, Domi T, deVeber G. Post-varicella arteriopathy of childhood: natural history of vascular stenosis. Neurology 2005;64(04):660-663

33 Pandey AS, Hill E, Al-Holou WN, et al. Management of pediatric craniocervical arterial dissections. Childs Nerv Syst 2015;31(01): 101-107

34 Dlamini N, Freeman JL, Mackay MT, et al. Intracranial dissection mimicking transient cerebral arteriopathy in childhood arterial ischemic stroke. J Child Neurol 2011;26(09):1203 1206

35 Kim JS. Moyamoya disease: epidemiology, clinical features, and diagnosis. J Stroke 2016;18(01):2-11

36 Bang OY, Fujimura M, Kim SK. The pathophysiology of Moyamoya disease: an update. J Stroke 2016;18(01):12-20

37 Elkind MS, Hills NK, Glaser CA, et al; VIPS Investigators*. Herpesvirus infections and childhood arterial ischemic stroke: results of the VIPS study. Circulation 2016;133(08):732-741

38 Fullerton HJ, Hills NK, Elkind MS, et al; VIPS Investigators. Infection, vaccination, and childhood arterial ischemic stroke: results of the VIPS study. Neurology 2015;85(17):1459-1466

39 Wintermark M, Hills NK, deVeber GA, et al; VIPS Investigators. Arteriopathy diagnosis in childhood arterial ischemic stroke: results of the vascular effects of infection in pediatric stroke study. Stroke 2014;45(12):3597-3605

40 Dowling MM, Hynan LS, Lo W, et al; International Paediatric Stroke Study Group. International Paediatric Stroke Study: stroke associated with cardiac disorders. Int J Stroke 2013;8(Suppl A100):39-44

41 Khan R, Chan AK, Mondal TK, Paes BA; Thrombosis and Hemostasis in Newborns (THIN) Group. Patent foramen ovale and stroke in childhood: a systematic review of the literature. Eur J Paediatr Neurol 2016;20(04):500-511

42 Barnes C, Deveber G. Prothrombotic abnormalities in childhood ischaemic stroke. Thromb Res 2006;118(01):67-74
43 Nestoridi E, Buonanno FS, Jones RM, et al. Arterial ischemic stroke in childhood: the role of plasma-phase risk factors. Curr Opin Neurol 2002;15(02):139-144

44 Mirsky DM, Beslow LA, Amlie-Lefond C, et al; International Paediatric Stroke Study Neuroimaging Consortium and the Paediatric Stroke Neuroimaging Consortium. Pathways for neuroimaging of childhood stroke. Pediatr Neurol 2017;69:11-23

45 Rivkin MJ, Bernard TJ, Dowling MM, Amlie-Lefond C. Guidelines for urgent management of stroke in children. Pediatr Neurol 2016; 56:8-17

46 Cario H, Grosse R, Jarisch A, Kulozik A, Kunz J, Lobitz S. Sichelzellkrankheit. AWMF-Leitlinie 025/016. 2014. Available at: https:// www.awmf.org/uploads/tx_szleitlinien/025-016l_S2k_Sichelzellkrankheit_2014-12_abgelaufen.pdf

47 Ferriero DM, Fullerton HJ, Bernard TJ, et al; American Heart Association Stroke Council and Council on Cardiovascular and Stroke Nursing. Management of stroke in neonates and children: a scientific statement from the American Heart Association/American Stroke Association. Stroke 2019;50(03):e51-e96

48 Medley TL, Miteff C, Andrews I, et al. Australian Clinical Consensus Guideline: The diagnosis and acute management of childhood stroke. Int J Stroke 2019;14(01):94-106

49 Rivkin MJ, deVeber G, Ichord RN, et al. Thrombolysis in pediatric stroke study. Stroke 2015;46(03):880-885

50 Berkhemer OA, Fransen PS, Beumer D, et al; MR CLEAN Investigators. A randomized trial of intraarterial treatment for acute ischemic stroke. N Engl J Med 2015;372(01):11-20

51 Campbell BC, Mitchell PJ, Kleinig TJ, et al; EXTEND-IA Investigators. Endovascular therapy for ischemic stroke with perfusionimaging selection. N Engl J Med 2015;372(11):1009-1018

52 Goyal M, Demchuk AM, Menon BK, et al; ESCAPE Trial Investigators. Randomized assessment of rapid endovascular treatment of ischemic stroke. N Engl J Med 2015;372(11):1019-1030

53 Jovin TG, Chamorro A, Cobo E, et al; REVASCAT Trial Investigators. Thrombectomy within 8 hours after symptom onset in ischemic stroke. N Engl J Med 2015;372(24):2296-2306

54 Saver JL, Goyal M, Bonafe A, et al; SWIFT PRIME Investigators. Stent-retriever thrombectomy after intravenous t-PA vs. t-PA alone in stroke. N Engl J Med 2015;372(24):2285-2295

55 Bigi S, Dulcey A, Gralla J, et al. Feasibility, safety, and outcome of recanalization treatment in childhood stroke. Ann Neurol 2018; 83(06):1125-1132

56 Gerstl L, Olivieri M, Heinen F, et al. Successful mechanical thrombectomy in a three-year-old boy with cardioembolic occlusion of both the basilar artery and the left middle cerebral artery. Eur J Paediatr Neurol 2016;20(06):962-965

57 Pacheco JT, Siepmann T, Barlinn J, et al. Safety and efficacy of recanalization therapy in pediatric stroke: a systematic review and meta-analysis. Eur J Paediatr Neurol 2018;22(06):1035-1041

58 Sporns PB, Kemmling A, Hanning U, et al. Thrombectomy in childhood stroke. J Am Heart Assoc 2019;8(05):e011335

59 Bhatia K, Kortman H, Blair C, et al. Mechanical thrombectomy in pediatric stroke: systematic review, individual patient data metaanalysis, and case series. J Neurosurg Pediatr 2019 Aug 9:1-14. doi: 10.3171/2019.5.PEDS19126. [Epub ahead of print]

60 Sporns PB, Sträter R, Minnerup J, et al. Feasibility, safety, and outcome of endovascular recanalization in childhood stroke: the Save ChildS Study. JAMA Neurol 2019

61 DeVeber G, Kirkham F. Guidelines for the treatment and prevention of stroke in children. Lancet Neurol 2008;7(11):983-985

62 Monagle P, Chan AKC, Goldenberg NA, et al. Antithrombotic therapy in neonates and children: Antithrombotic Therapy and Prevention of Thrombosis, 9th ed: American College of Chest Physicians evidence-based clinical practice guidelines. Chest 2012;141(2, Suppl):e737S-e801S

63 Stence NV, Fenton LZ, Goldenberg NA, Armstrong-Wells J, Bernard TJ. Craniocervical arterial dissection in children: diagnosis and treatment. Curr Treat Options Neurol 2011;13(06):636-648 
64 Kurnik K, Bidlingmaier C, Hütker S, Olivieri M. Haemostatic disorders in children [in German]. Hamostaseologie 2016;36(02):109-125

65 Boucher AA, Taylor JM, Luchtman-Jones L. Aspirin in childhood acute ischemic stroke: the evidence for treatment and efficacy testing. Pediatr Blood Cancer 2019;66(06):e27665

66 Steinlin M, Bigi S, Stojanovski B, et al; Swiss NeuroPediatric Stroke Registry. Focal cerebral arteriopathy: do steroids improve outcome? Stroke 2017;48(09):2375-2382

67 Goldenberg NA, Bernard TJ, Fullerton HJ, Gordon A, deVeber G; International Pediatric Stroke Study Group. Antithrombotic treatments, outcomes, and prognostic factors in acute childhoodonset arterial ischaemic stroke: a multicentre, observational, cohort study. Lancet Neurol 2009;8(12):1120-1127

68 Sträter R, Becker S, von Eckardstein A, et al. Prospective assessment of risk factors for recurrent stroke during childhood-a 5-year follow-up study. Lancet 2002;360(9345):1540-1545
69 deVeber G, Kirkham F, Shannon K, et al. Recurrent stroke: the role of thrombophilia in a large international pediatric stroke population. Haematologica 2019;104(10):2116

70 Fox CK, Glass HC, Sidney S, Lowenstein DH, Fullerton HJ. Acute seizures predict epilepsy after childhood stroke. Ann Neurol 2013;74(02):249-256

71 Hsu CJ, Weng WC, Peng SS, Lee WT. Early-onset seizures are correlated with late-onset seizures in children with arterial ischemic stroke. Stroke 2014;45(04):1161-1163

72 Mallick AA, Ganesan V, Kirkham FJ, et al. Outcome and recurrence 1 year after pediatric arterial ischemic stroke in a populationbased cohort. Ann Neurol 2016;79(05):784-793

73 Ghotra SK, Johnson JA, Qiu W, Newton AS, Rasmussen C, Yager JY. Health-related quality of life and its determinants in paediatric arterial ischaemic stroke survivors. Arch Dis Child 2018;103(10): 930-936 